\title{
Radiological Assessment of Dysbaric Osteonecrosis as a Part of Fitness-to-dive Examinations
}

\author{
Dalışa Uygunluk Muayenelerinin Bir Parçası Olarak Disbarik Osteonekroz \\ Değerlendirmeleri
}

\author{
(D) Șefika Körpınar¹, (D) Nilüfer Aylanç², (D) Șenay Bengin Ertem², (D) Mustafa Resorlu² \\ ${ }^{1}$ Çanakkale Onsekiz Mart University Faculty of Medicine, Department of Underwater and Hyperbaric Medicine, Çanakkale, Turkey \\ ${ }^{2}$ Çanakkale Onsekiz Mart University Faculty of Medicine, Department of Radiology, Çanakkale, Turkey
}

\begin{abstract}
Introduction: It is important for professional divers and candidates to be medically and physically fit to undertake their underwater work safely. This study aimed to review the screening of dysbaric osteonecrosis (DON) using conventional radiography, which has been stated in the legislation as part of fitness-to-dive examinations, in terms of international standards and scientific facts.
\end{abstract}

Methods: Data on clinical, demographic, laboratory, and radiological evaluations were retrospectively collected for 46 professional divers or candidates who were referred for fitnessto-dive examinations between 2018 and 2020. The approach of the Professional Divers Regulation to DON was compared with that of the Military Health Regulation for the Turkish Armed Forces and the Turkish Underwater Sports Federation Equipped Diving Instruction, as well as that of the legislation of United Kingdom and European Diving Technology Committee standards.

Results: Forty-six divers (males: $n=45$; female: $n=1$ ) were enrolled in the study. Their median age was 34 (range: 18-63) years, and the mean body mass index was $25.42 \mathrm{~kg} / \mathrm{m}^{2}$. The prevalence of DON was $2.17 \%$ in the study group. Compared with the national and international legislations, Professional Diver Regulation was the only regulation that mandated radiological evaluation for DON in both the initial and periodic fitness-to-dive examinations.

Conclusion: One of the aims of regulations is that medical fitness-to-dive standards should be evidence-based and compatible with contemporaneous clinical practice. By the 2000s, attitudes toward DON, fitness to continue diving, and compressed air work have changed in Europe. In light of the findings of the present study, we believe that it is time for a critical reappraisal of the Professional Divers Regulation.

Keywords: Dysbaric osteonecrosis, fitness-to-dive examinations, radiology

\section{öz}

Amaç: Profesyonel dalgıç ve dalgıç adaylarının sualtı çalıșmalarını güvenli bir șekilde gerçekleștirebilmeleri için dalışa, tıbbi, mental ve fiziksel açıdan uygun olmaları önemlidir. Bu çalışmada, dalışa uygunluk muayenelerinin bir parçası olarak mevzuatta belirlenmiş haliyle radyolojik disbarik osteonekroz (DON) değerlendirmelerinin uluslararası standartlar ve bilimsel gerçekler açısından gözden geçirilmesi amaçlanmıştır.

Yöntemler: 2018-2020 yılları arasında dalıșa uygunluk muayeneleri için başvuran 46 profesyonel dalgıç veya adayının klinik, demografik, laboratuvar ve radyolojik değerlendirmeleri retrospektif olarak incelendi. Profesyonel Sualtıadamları Yönetmeliği'nin DON yaklaşımı, Türk Silahlı Kuvvetleri Sağlık Yeteneği Yönetmeliği, Türkiye Sualtı Sporları Federasyonu Donanımlı Dalış Talimatı, Birleșik Kralık Mevzuatı ve Avrupa Dalış Teknolojisi Komitesi standartları ile karşılaştıııldı.

Bulgular: Çalışma süresi boyunca kırk altı dalgıç (erkek: $n=45$; kadın: n=1) bașvurmuștu. Ortanca yaş 34 (18-63 aralığında) ve ortalama vücut kitle indeksi $25,42 \mathrm{~kg} / \mathrm{m}^{2}$ idi. Çalışma grubumuzda DON prevalansı \%2,17 tespit edildi. Profesyonel Sualtıadamları Yönetmeliği, bu çalışma kapsamında incelenen ulusal ve uluslararası mevzuatla karșılaștıııldığında hem başlangıç hem de periyodik dalışa uygunluk muayenelerinde DON açısından radyolojik değerlendirmeyi zorunlu kılan tek yönetmeliktir.

Sonuç: Yönetmeliklerin düzenlenme amaçlarından biri de, dalış için tıbbi uygunluk standartlarının kanıta dayalı ve çağdaş klinik uygulamalarla uyumlu olmasıdır. 2000'li yıllarla birlikte, DON, dalışa ve basınçlı hava çalışmalarına devam edebilme kriterlerine yönelik bakış açısı ve tutumlar tüm Avrupa'da değișmiștir. Bu çalıșmadan elde ettiğimiz veriler ışı̆̆ında, Profesyonel Sualtıadamları Yönetmeliği'nin eleștirel bir şekilde yeniden değerlendirme zamanının geldiğini düşünüyoruz.

Anahtar Kelimeler: Disbarik osteonekroz, dalışa uygunluk muayeneleri, radyoloji 


\section{Introduction}

It is important for professional divers and candidates to be medically and physically fit to participate in the underwater work safely. Being unfit to dive is a risk to the divers themselves as well as to other members involved in conducting the activity underwater. Health and safety considerations in professional diving are specified by the regulations in Turkey, as in all other countries globally. The regulations aim to enhance the quality and reduce any unnecessary variability of fitness-to-dive assessments, thereby establish national standards. International standardization of fitness-to-dive examinations is an issue declared and studied by the European Diving Technology Committee (EDTC), since 1999 (1). In our country, these examinations are conducted in accordance with the Professional Divers Regulation issued in 1997 by the Ministry of Transportation, Maritime Affairs and Communication. Aspects that are to be considered while evaluating the musculoskeletal system in the aforementioned regulation have been stated as follows: "All extremities of professional divers should be in integrity and extremity movements within normal limits. It is mandatory to perform radiological assessments in terms of dysbaric osteonecrosis (DON) during the initial and periodical examinations" (2). X-rays of hips, shoulders, and knees have been used as a standard for these mandatory radiological assessments since the introduction of the regulation. Furthermore, these radiological examinations are repeated biennially since the interval of medical assessments is determined as two years.

In this study, we aimed to review DON screening performed using $\mathrm{X}$-rays as determined in the legislation, as part of the fitness-to-dive examinations in our country, from the point of view of international standards and scientific facts.

\section{Methods}

This was a retrospective cross-sectional study. After approval from the Clinical Research Ethics Committee of Çanakkale Onsekiz Mart University (approval number: 2020/12, date: 09.23.2020), data extraction was performed by retrospectively assessing the medical records of all professional divers and candidates who were referred for the fitnessto-dive examination to Çanakkale Onsekiz Mart University Faculty of Medicine, Department of Underwater and Hyperbaric Medicine, between June 2018, and September 2020. Informed consent was not obtained owing to the retrospective nature of the study. The following data were evaluated: Demographic characteristics, body mass index (BMI), past and current diseases, medications, steroid use, tobacco use, alcohol intake, diving experience (years of diving and total diving time), maximum diving depth, history of omitted decompression and decompression sickness (DCS), blood profile (complete blood counts, erythrocyte sedimentation rate, serum cholesterol, triglyceride, aspartate transaminase, alanine transaminase, urea, creatinine, and fasting blood glucose), urine analysis, radiologic evaluations [X-rays of hips, shoulders, and knees and (if performed) magnetic resonance imaging (MRI)].

The approach of the national legislation to DON, as part of fitness-todive examinations for professional divers (2), was compared with the Military Health Regulation for the Turkish Armed Forces (3) and the Turkish Underwater Sports Federation Equipped Diving Instruction (4), as well as the legislation of Health and Safety Executive (HSE) in UK (5) and EDTC standards (1).

\section{Statistical Analysis}

The IBM SPSS Statistics for Windows, Version 19.0, (IBM Corp, Chicago, IL, USA) was used to analyze data. Quantitative variables were expressed as means \pm standard deviations, whereas categorical variables were expressed as numbers and percentages.

\section{Results}

In total, 46 individuals (males: $n=45$, female: $n=1$ ) were referred during the study period. The median age of participants was 34 (range: 18-63) years, and their mean BMI was $25.42 \mathrm{~kg} / \mathrm{m}^{2}$. The mean diving time was 2736 hours, and besides participating in scuba and using hookah or surface supplied diving systems, 28 divers (60.8\%) were also performing freediving. The breathing mixture used was air; however, four individuals had also performed dives using trimix and nitrox. The average of maximum dive depth was $39.4 \mathrm{~m}$ (range: 15-80) seawater, and the average bottom time was $11.6 \mathrm{~min}$. Three divers had a history of musculoskeletal DCS, of which two reported the disease twice. Twenty-two divers (47.8\%) had been screened for DON once or more than once during previous fitness-to-dive examinations via X-ray imaging of the hips, shoulders, and knees. Biochemical examinations revealed high levels of serum/plasma cholesterol and/or triglycerides in 18 (39.1\%) divers. Oral glucose tolerance test revealed that four divers had impaired fasting glucose (fasting plasma glucose values between 100 to $125 \mathrm{mg} / \mathrm{dL}$ ); for these, a change in diet was recommended. After 6 months, fasting glucose levels measured for these divers were within the normal range. In addition, 52.1\% divers reported that they did not consume alcohol. Two divers who reported using alcohol had a habit of regular alcohol consumption. Only one diver had a history of shortterm, high-dose steroid use. The demographic, clinical, and laboratory characteristics of divers are summarized in Table 1.

Bilateral anteroposterior radiographs of the shoulders, hips, and knee joints revealed DON lesions at the humeral head and neck in only one of the 46 divers. The diver had a history of acute DCS and 40 years of diving career, when factors associated with the occurrence of lesions were evaluated, including age, diving experience, and physical factors (6). The prevalence of DON was $2.17 \%$ in our study.

When the approach of Professional Divers Regulation for medical surveillance of DON (2) was compared with that of other regulations, the following results were determined. 1) According to the Military Health Regulation for the Turkish Armed Forces, Item 59 (3); "in divers and frogmen, screening for DON disease, which can develop related to diving, is performed at the discretion of the underwater and hyperbaric medicine specialist" (3). 2) TSSF Equipped Diving Instruction, Sixth Section, Health Conditions, Item 20e states that "since DON is an occupational disease, it is recommended that a skeletal survey (X-ray or MRI) be performed at the first examinations for the detection of DON because these images will provide a baseline for future reference; however, it is not mandatory. Screening for DON is not mandatory in cases where there are no complaints or signs of physical examination in control examinations. However, according to the results of the physical 
examination, additional examinations for diseases of the skeletal system may be requested at the discretion of the underwater and hyperbaric medicine specialist" (4). 3) According to the Medical Examination and Assessment of Professional Divers (MA1) that meets HSE standards and guidelines for the MA1 in UK, "the diver must have the appropriate degree of mobility, strength and dexterity for the diving activities and work undertaken. Musculoskeletal problems require a careful and individual risk assessment. Routine long-bone X-rays are not required for surveillance of divers. Long-bone radiography and/or MRI is indicated

\begin{tabular}{|c|c|}
\hline Age, years (mean \pm SD) & $34.4 \pm 10.8$ \\
\hline \multicolumn{2}{|l|}{ Sex, $n(\%)$} \\
\hline Male & $45(97.8 \%)$ \\
\hline Female & $1(2.1 \%)$ \\
\hline Body mass index, $\mathrm{kg} / \mathrm{m}^{2}$ (mean $\left.\pm \mathrm{SD}\right)$ & $25.4 \pm 3.0$ \\
\hline Diving experience, years (mean $\pm S D$ ) & $11.4 \pm 10.6$ \\
\hline Total diving time, hours (mean $\pm S D$ ) & $2736.6 \pm 4420$ \\
\hline$\leq 100$ & $11(23.9 \%)$ \\
\hline $100-1000$ & $14(30.4 \%)$ \\
\hline$>1000-5000$ & $15(32.6 \%)$ \\
\hline$\geq 5000$ & $6(13.0 \%)$ \\
\hline History of musculoskeletal DCS, $n$ (\%) & $3(6.5 \%)$ \\
\hline Maximum diving depth, $m$ seawater (mean \pm SD) & $39.4 \pm 22.4$ \\
\hline \multicolumn{2}{|l|}{ Type of diving activity, $n$ (\%) } \\
\hline Professional inshore/offshore diver & $21(45.6 \%)$ \\
\hline Sea harvesting diver & $21(45.6 \%)$ \\
\hline Directorate general of coastal safety diver & $2(4.3 \%)$ \\
\hline Fish farm diver & $2(4.3 \%)$ \\
\hline Smoking & $27(58.6 \%)$ \\
\hline Alcohol consumption & $22(47.8 \%)$ \\
\hline \multicolumn{2}{|l|}{ Biochemical parameters } \\
\hline Fasting blood glucose, $\mathrm{mg} / \mathrm{dL}$ (mean $\pm \mathrm{SD}$ ) & $95.1 \pm 9.3$ \\
\hline Erythrocyte sedimentation rate, $\mathrm{mm} / \mathrm{h}$ (mean $\pm \mathrm{SD}$ ) & $6.8 \pm 4.2$ \\
\hline Total cholesterol, mg/dL (mean \pm SD) & $183.1 \pm 48.0$ \\
\hline Triglyceride level, mg/dL, (mean \pm SD) & $148.6 \pm 180.6$ \\
\hline Urea, mg/dL (mean \pm SD) & $27.5 \pm 7.3$ \\
\hline Creatinine, mg/dL (mean \pm SD) & $0.9 \pm 0.1$ \\
\hline Alanine transaminase, $\mathrm{U} / \mathrm{L}$ (mean $\pm \mathrm{SD}$ ) & $23.4 \pm 9.3$ \\
\hline Aspartate transaminase, $\mathrm{U} / \mathrm{L}($ mean $\pm \mathrm{SD})$ & $28.1 \pm 19.2$ \\
\hline White blood cell count, $10^{9} / \mathrm{L}$ (mean \pm SD) & $7.2 \pm 1.8$ \\
\hline Hemoglobin, gr/dL (mean \pm SD) & $15.6 \pm 1.1$ \\
\hline Hematocrit, \% (mean \pm SD) & $44.7 \pm 2.9$ \\
\hline $\begin{array}{l}\text { History of previously been performed DON screening } \\
\text { using X-ray, } n(\%)\end{array}$ & $\mathbf{n}$ \\
\hline Yes & $22(47.8 \%)$ \\
\hline Once & $6(13.0 \%)$ \\
\hline More than once & $16(34.7 \%)$ \\
\hline No & $24(52.1 \%)$ \\
\hline
\end{tabular}

DCS: Decompression sickness, DON: dysbaric osteonecrosis, SD: standard deviation in cases of suspected DON" (5). 4) The recommendations of EDTC in which our country is represented in the medical category - on the DON are as follows: "As a standard, screening is needed only for divers with more than 20 hours per week underwater or diving of over $30 \mathrm{~m}$. Bone X-rays were standard for many years, but they will be replaced in the future by MRI as this technique allows screening without the use of ionizing radiation, which makes it ethically more acceptable (in spite of the increased costs)." "... all new entrants on graduating should be considered for baseline long-bone imaging." "These records must be stored longer than the lifetime career of the diver." "Those found to have bone necrosis are not necessarily unfit for diving. If the lesion is in the shaft of a bone (B lesion), the diver is not at risk from joint collapse and the condition has no effect on underwater safety. A juxta-articular (JA) lesion is more serious but, again, is unlikely to affect underwater safety and so medical disqualification cannot be for that reason alone. The strong advice to give up diving is based on the need for the individual to avoid excessive weight bearing at that joint" (1).

\section{Discussion}

DON is recognized as an important occupational health hazard in individuals who regularly exposed to hyperbaric environments in their professions, such as commercial divers and compressed air workers, despite adherence to recognized decompression procedures. Thus, it is a condition that deserves compensation in some way; however, it is not, on its own, an outcome of employer negligence. It is more common in those with a record of DCS treatment and can occur after a single exposure to pressure alone. Although omitted decompression after prolonged hyperbaric exposure is the major etiologic factor, the precise pathogenesis of DON is still unclear $(1,7)$. In this context, the main findings of this study were as follows: 1 ) overall, the incidence of DON was $2.17 \%$ in our study which included 46 divers with different professional goals; 2) the Professional Diver Regulation (2) is the only regulation that mandates radiological evaluation for DON in both initial and periodic fitness-to-dive examinations when compared with the national and international legislations reviewed in this study; 3) according to the aforementioned regulation, the presence of DON lesions alone, whether localized in JA or head, neck, and shaft (HNS), cannot be a reason for medical disqualification; and 4) although conventional radiography has been used as the standard for many years, MRI is now the preferred initial screening technique to detect abnormalities in the long bone, which could be indicative of DON as with other aseptic necrosis of bone.

Imaging is crucial for diagnosing DON as the ischemic episode is painless, or because deep throbbing joint pain with or without passive and active range of motion occur weeks, months, or even years following exposure (8). Conventional radiography is the simplest, most readily available, and generally accepted means of confirming lesion diagnosis. A radiological description of the lesions and their classification have been provided by Davidson (9). According to this classification, JA lesions are more important than HNS lesions, because JA lesions, which occur relatively less frequently in divers and much more commonly in compressed air workers result in the collapse of the articular surface and the development of secondary osteoarthritis. The incidence and contributing factors of the disease have been 
reviewed with X-rays by the British Medical Research Council (MRC) Decompression Sickness Central Registry in commercial divers. The registry's guidance notes for radiological skeletal surveys, which include the proximal ends of humerus and femur and the shafts of femur and tibia, are still being used in the diving medicine routine, as it was first prepared $(6,9)$. However, unfortunately, is not sensitive for early stages of osteonecrosis (6-11). The time from dysbaric insult to the earliest radiological sign, characterized by an absolute increase in radiological density could take at least 6 months (9). MRI is the leading candidate against the decades-long throne of $\mathrm{X}$-rays, as it allows scanning without the use of ionizing radiation, which makes it more ethically acceptable despite the increased costs. Although doses are as low as about 0.06 $\mathrm{mSv}$, limb joints radiographs along with chest and teeth constitute a significant part of the annual individual and collective effective doses from diagnostic medical X-rays. This value has been estimated as 0.5 mSv and 130,000 person-Sv (12,13). MRI is the leading candidate against the decades-long throne of $X$-rays, as it allows scanning without the use of ionizing radiation, which makes it more ethically acceptable despite the increased costs. Contrast may be increased by the combination of T1 sequences with fat-suppressed short tau inversion recovery sequences as well as with the use of high-resolution surface coils (7). However, the fact that a number of early changes detected on MRI turn out to be false positives which then disappear -since some lesions probably heal without leaving a necrotic infarct- may raise the question of the timing of the imaging. EDTC recommends that all new entrants should be considered for baseline long-bone imaging on graduating; in addition, all those who dive regularly for $>30$ meters and $>4$ hours under pressure should undergo routine health surveillance along with those who have clinical symptoms, those with referable to a joint, and for those who have had a DCS (1). It has been also suggested that divers treated for musculoskeletal DCS should be routinely screened using MRI for the initial findings of DON (11).

Although many studies have determined the prevalence of DON among those who dive for different professional purposes, there are no data on the prevalence among divers examined in accordance with the professional diver regulation in our country. The prevalence of $2.17 \%$ observed in our study is higher than that observed in navy divers, who strictly follow the decompression rules and undergo periodic medical examinations (14). However, it is considerably lower than the prevalence of $70.6 \%$ in another study enrolling Turkish sponge divers who were not subjected to a proper training program for diving, did not use any particular decompression table, and among whom most had a history of DCS (15). These high figures are neither unique to our country nor to sponge divers. Similar rates have been also observed among Yucatán Mexican artisanal diving fishermen (16). Whatever the sponge, fish or sea snails, collection strategies are inevitably influenced by economic pressures, which implies that individuals diving for such commercial purposes subjects themselves to more risky and provocative dive profiles. In contrast, the prevalence of $2.17 \%$ obtained in our study is lower than the prevalence of $4.2 \%$ reported by British MRC Decompression Sickness Central Registry, which evaluated 4980 commercial divers (6). This may be attributed to the fact that our study included a relatively smaller cohort.
Undoubtedly, one of the aims of regulations is that medical fitness standards are evidence-based and compatible with contemporaneous clinical practice. By the 2000s, attitudes toward DON and fitness to continue diving and compressed air work have changed all around Europe. EDTC took the lead to give diving medicine physicians the competence to perform a differentiated assessment according to diving task-based criteria and abandon the rigid assessment style. The perspective that was being attempted to be instilled in the fitness-todive examinations was that a strong reason must be adduced before a diver is deprived of his/her jobs and before his/her experience is lost from the industry $(1,17)$.

\section{Conclusion}

On the basis of these considerations, we propose the following topics for reconsideration by regulatory authorities. For the reasons of feasibility described above, conventional radiography has been used as a standard method for many years. However, even if deemed advantageous, it would be difficult to scientifically explain biennial exposure to ionizing radiation, and the delay from the known first hyperbaric exposure to the appearance of the first radiological findings. Thus, we suggest that such screening may be neither necessary nor advisable and therefore should be reconsidered. Despite the increased costs, MRI allows screening without using ionizing radiation, which makes it ethically more acceptable. In light of the above considerations, we believe that it is time for a critical reappraisal of the Professional Divers Regulation.

Ethics Committee Approval: The approval form the the Clinical Research Ethics Committee of Çanakkale Onsekiz Mart University was obtained (approval number: 2020/12, date: 09.23.2020).

Informed Consent: Informed consent was not obtained owing to the retrospective nature of the study.

Peer-review: Externally peer-reviewed.

Authorship Contributions: Surgical and Medical Practices - S..K., N.A., S.B.E., M.R.; Concept - \$.K.; Design - \$.K.; Data Collection or Processing S.K., N.A., S.B.E., M.R.; Analysis or Interpretation - S.K., N.A., S.B.E., M.R.; Literature Search - \$.K., N.A., S.B.E., M.R.; Writing - \$.K.

Conflict of Interest: No conflict of interest was declared by the authors.

Financial Disclosure: The authors declared that this study received no financial support.

\section{References}

1. Fitness to Dive Standards of European Diving Technology Committee. Edited by Jürg Wendling, David Elliott and Tor Nome. Published by European Diving Technology Committee, 2004.

2. T.C. Resmi Gazete. Profesyonel Sualtıadamları Yönetmeliği. 1997; 23098: pp. 16. http://www.resmigazete.gov.tr/main.aspx?home=http://www resmigazete.gov.tr/arsiv/23098.pdf\&main=http://www.resmigazete.gov.tr/ arsiv/23098.pdf

3. T.C. Resmi Gazete. Türk Silahlı Kuvvetleri, Jandarma Genel Komutanlığı ve Sahil Güvenlik Komutanlığı Sağlık Yeteneği Yönetmeliği. http://www. resmigazete.gov.tr/eskiler/2016/11/20161111-26.pdf 
4. Türkiye Sualtı Sporları Federasyonu Donanımlı Dalış Talimatı (GSGM Y.T. 20.03.2017. Değişiklik 06.05.2019) https://tssf.gov.tr/yonetmelik-ve-talimatlar/

5. The medical examination and assessment of divers (MA1). MA1 (rev4), Published 10/15. https://www.hse.gov.uk/pubns/ma1.pdf

6. Aseptic bone necrosis in commercial divers. A report from the Decompression Sickness Central Registry and Radiological Panel. Lancet 1981; 2: 384-8.

7. Bolte H, Koch A, Tetzlaff K, Bettinghausen E, Heller M, Reuter M. Detection of dysbaric osteonecrosis in military divers using magnetic resonance imaging. Eur Radiol 2005; 15: 368-75.

8. Sharareh B, Schwarzkopf R. Dysbaric osteonecrosis: a literature review of pathophysiology, clinical presentation, and management. Clin J Sport Med 2015; 25: 153-61.

9. Davidson JK. Dysbaric disorders: aseptic bone necrosis in tunnel workers and divers. Baillieres Clin Rheumatol 1989; 3: 1-23.

10. Shinoda S, Hasegawa Y, Kawasaki S, Tagawa N, Iwata H. Magnetic resonance imaging of osteonecrosis in divers: comparison with plain radiographs. Skeletal Radiol 1997; 26: 354-9.

11. Gempp E, Blatteau JE, Simon O, Stephant E. Musculoskeletal decompression sickness and risk of dysbaric osteonecrosis in recreational divers. Diving Hyperb Med 2009; 39: 200-4.
12. UNSCEAR (United Nations Scientific Committee on the Effects of Atomic Radiation). Sources and Effects of Ionizing Radiation. UNSCEAR Report to the General Assembly, Volume I: Sources. New York: United Nations; 2000a.

13. UNSCEAR (United Nations Scientific Committee on the Effects of Atomic Radiation). Sources and Effects of Ionizing Radiation. UNSCEAR Report to the General Assembly, Volume II: Effects. New York: United Nations; 2000b.

14. Uzun G, Toklu AS, Yildiz S, Sonmez G, Aktaş S, Sezer H, et al. Dysbaric osteonecrosis screening in Turkish Navy divers. Aviat Space Environ Med 2008; 79: 44-6.

15. Toklu AS, Cimșit M. Dysbaric osteonecrosis in Turkish sponge divers. Undersea Hyperb Med 2001; 28: 83-8.

16. Popa D, Medak A, Chin W, Huchim-Lara O, Fliszar E, Hughes T, et al. Dysbaric osteonecrosis (DON) among the artisanal diving fishermen of Yucatán, Mexico. Diving Hyperb Med 2020; 50: 391-8.

17. King J. Health effects on hyperbaric environments. In: Waldron HA, (Eds). Occupational Health Practice. 3rd Ed. Butterworths \& Co (Publishers) Ltd 1989; pp. 415-30. 